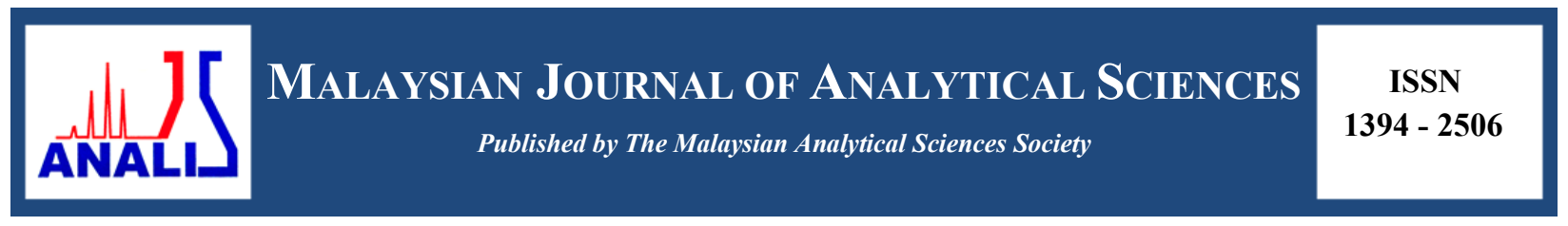

\title{
EFFECT OF SILVER ON THE PHYSICAL AND STRUCTURAL PROPERTIES OF LEAD NEODYMIUM BOROTELLURITE GLASS SYSTEM
}

\author{
(Kesan Perak atas Sifat Fizikal dan Struktur Sistem Kaca Plumbum Neodimium Borotelurit) \\ Norihan Yahya ${ }^{1}$, Azman Kasim ${ }^{1}$, Azhan Hashim ${ }^{1}$, Siti Nasuha Rafien ${ }^{1}$, Wan Aizuddin Wan Razali ${ }^{1}$, \\ Syamsyir Akmal Senawi ${ }^{1}$, Ruziana Mohamed ${ }^{1}$, Mardhiah Abdullah ${ }^{2}$ \\ ${ }^{I}$ Faculty of Applied Sciences, \\ Universiti Teknologi MARA Cawangan Pahang, 26400 Bandar Tun Abdul Razak Jengka, Pahang, Malaysia \\ ${ }^{2}$ Faculty of Applied Sciences, \\ Universiti Teknologi MARA Cawangan Terengganu, Kampus Bukit Besi, 23200 Dungun,Terengganu, Malaysia
}

*Corresponding author: norihan@pahang.uitm.edu.my

Received: 4 December 2016; Accepted: 1 December 2017

\begin{abstract}
Neodymium doped borotellurite glass is well known to be one of the most promising candidate due to it various applications. $\mathrm{Nd}^{3+}$ doped lead borotellurite glasses containing silver were successfully been prepared by conventional melt-quenching method with the chemical composition (69.5-x) $\mathrm{TeO}_{2}-20 \mathrm{~B}_{2} \mathrm{O}_{3}-10 \mathrm{PbO}-0.5 \mathrm{Nd}_{2} \mathrm{O}_{3}-x \mathrm{AgNO}_{3}$ (where $x=0,0.5,1.0,1.5,2.0$ and $2.5 \mathrm{~mol} \%$ ). The physical properties such as density, molar volume and oxygen packing density were measured. Their structural properties of the glass system were studied via X-Ray Diffraction (XRD) analysis and Fourier Transform Infrared (FTIR) spectroscopy. From the result, the amorphous nature of the prepared glass samples have been confirmed through X-ray diffraction spectral analysis. The presence of Te-O-Te or O-Te-O, Ag-O, Te-O-Pb and B-O and characteristic of the hydrogen bond in the prepared glasses were explored through the FTIR spectral studies recorded in the $400-4000 \mathrm{~cm}^{-1}$ wave number range at room temperature. Meanwhile, the results of physical properties are found to vary with respect to concentration of $\mathrm{AgNO}_{3}$ content. Some other results will be reported and discussed.
\end{abstract}

Keywords: neodymium, borotellurite, silver, physical properties, structural properties

\begin{abstract}
Abstrak
Kaca borotelurit di dop neodimium merupakan salah satu bahan yang diyakini disebabkan oleh kepelbagaian aplikasinya. Kaca borotelurit di dop $\mathrm{Nd}^{3+}$ mengandungi perak telah berjaya disediakan dengan kaedah konvensional sepuh lindap dengan komposisi kimia $(69.5-x) \mathrm{TeO}_{2}-20 \mathrm{~B}_{2} \mathrm{O}_{3}-10 \mathrm{PbO}-0.5 \mathrm{Nd}_{2} \mathrm{O}_{3}-x \mathrm{AgNO}_{3}$ (di mana $\mathrm{x}=0,0.5,1.0,1.5,2.0$ dan 2.5 mol\%). Sifat-sifat fizikal seperti ketumpatan, isipadu molar dan ketumpatan padat oksigen telah diukur. Sifat-sifat struktur sistem kaca ini telah dikaji melalui analisis pembelauan sinar-X (XRD) dan spektroskopi inframerah transformasi Fourier (FTIR). Dari hasil kajian, sifat semulajadi amorfus sampel kaca yang disediakan telah disahkan melalui analisis spektra pembelauan sinar-X. Kehadiran $\mathrm{Te}-\mathrm{O}-\mathrm{Te}$ atau $\mathrm{O}-\mathrm{Te}-\mathrm{O}$, Ag-O, Te-O-Pb, B-O dan ciri-ciri ikatan hidrogen dalam kaca yang disediakan telah diterokai melalui kajian spektra FTIR yang direkodkan dalam julat gelombang $400-4000 \mathrm{~cm}^{-1}$ pada suhu bilik. Sementara itu, hasil kajian bagi sifat fizikal didapati berubah mengikut kepekatan kandungan $\mathrm{AgNO}_{3}$. Beberapa keputusan lain akan dilaporkan dan dibincangkan.
\end{abstract}

Kata kunci: neodimium, borotelurit, perak, sifat fizikal, sifat struktur 


\section{Norihan et al: EFFECT OF SILVER ON THE PHYSICAL AND STRUCTURAL PROPERTIES OF LEAD NEODYMIUM BOROTELLURITE GLASS SYSTEM}

\section{Introduction}

The physical and structural studies of glass oxide incorporated with various rare earth (RE) draw much attention due to their important role in the development of many optical devices such as infrared laser, colour display devices, optical detectors, light converters and sensors [1]. Among the oxide glass, lead borotellurite glass systems were much attractive due to their high density, high refractive index [2], low phonon energies $\left(\sim 700 \mathrm{~cm}^{-1}\right)$, extended infrared transmittance $(0.35-6.0 \mu \mathrm{m})$, large corrosion resistance, high mechanical strength and relatively high thermal stability $[3,4]$. The glass hosts are excellent candidate for laser applications due to their low cost as well as ease to fabricate in various geometries [5]. In the literature there are relatively few reports on the structural properties of glass doped with $\mathrm{Nd}^{3+}$ ions $[6,7]$. Recently study reported on the effects produced by the codoping with silver nitrate of glasses doped with various RE ions on the structural properties [8] that confer potential applications for these material. In this work, we prepared some $\mathrm{Nd}^{3+}$ doped lead borotellurite glass containing silver. The sample have a fixed $\mathrm{Nd}^{3+}$ and $\mathrm{PbO}$ content whereas the $\mathrm{TeO}_{2}: \mathrm{AgNO}_{3}$ content are varied. The physical properties by mean of their density, molar volume as well as the oxygen packing density (OPD) will be determined. Meanwhile, their structural study will be identify using the X-ray diffraction (XRD) and Fourier transform infrared (FTIR) spectroscopy. However, the aim of this study was to investigate the influence of silver on the physical and structural properties of the investigated materials.

\section{Materials and Methods}

Glasses with chemical composition $(69.5-x) \mathrm{TeO}_{2}-20 \mathrm{~B}_{2} \mathrm{O}_{3}-10 \mathrm{PbO}-0.5 \mathrm{Nd}_{2} \mathrm{O}_{3}-x \mathrm{AgNO}_{3}(x=0.0,0.5,1.0,1.5,2.0$ and $2.5 \mathrm{~mol} \%$ ) were prepared by a conventional melt-quenching method using reagents of analytical grade. The chemicals of the required compositions of approximately $10 \mathrm{~g}$ batches were weighed in an electrical balance and mixed thoroughly in milling process about 1 hour in order to obtain homogeneous mixtures. The mixture was melted at $1000{ }^{\circ} \mathrm{C}$ for 30 minutes in an electric box furnace. The mixture was then poured into stainless steel plate and immediately transferred into a preheated furnace for annealing process at temperature $400{ }^{\circ} \mathrm{C}$ for 3 hours before allowed to cool down gradually to room temperature. The glass samples of each composition were prepared and polished to obtain a planar faces for structural analysis. The composition of the investigated glasses are listed in Table 1.

Table 1. Chemical Composition of $(69.5-x) \mathrm{TeO}_{2}-20 \mathrm{~B}_{2} \mathrm{O}_{3}-10 \mathrm{PbO}-0.5 \mathrm{Nd}_{2} \mathrm{O}_{3}-x \mathrm{AgNO}_{3}$ glass system

\begin{tabular}{lccccc}
\hline \multirow{2}{*}{ Sample No } & \multicolumn{5}{c}{ Composition (mol\%) } \\
\cline { 2 - 6 } & $\mathbf{T e O}_{2}$ & $\mathbf{B}_{\mathbf{2}} \mathbf{O}_{\mathbf{3}}$ & $\mathbf{P b O}$ & $\mathbf{N d}_{\mathbf{2}} \mathbf{O}_{\mathbf{3}}$ & $\mathbf{A g N O}_{\mathbf{3}}$ \\
\hline S1 & 69.5 & 20 & 10 & 0.5 & 0.0 \\
S2 & 69.0 & 20 & 10 & 0.5 & 0.5 \\
S3 & 68.5 & 20 & 10 & 0.5 & 1.0 \\
S4 & 68.0 & 20 & 10 & 0.5 & 1.5 \\
S5 & 67.5 & 20 & 10 & 0.5 & 2.0 \\
S6 & 67.0 & 20 & 10 & 0.5 & 2.5 \\
\hline
\end{tabular}

The density of the glass samples was measured using distilled water as an immersion liquid by Archimedes' principle on a Electronic Densimeter MD-300S balance. Formula for calculating density, molar volume and oxygen packing density is given in Table 2. The structural properties of the glass samples were analyzed using X-Ray Diffraction (XRD) analysis which is performed at room temperature to confirmed its amorphous nature. The Fourier Transform Infrared (FTIR) spectroscopy absorption spectra of the glass samples were recorded on Perkin-Elmer Spectrum 100 FT-IR Spectrometer at room temperature in the wavenumber range $400-4000 \mathrm{~cm}^{-1}$ with a resolution of $4 \mathrm{~cm}^{-1}$. 
Table 2. Formulas for calculating physical properties of silver addition of lead borotellurite glass.

\begin{tabular}{|c|c|c|c|}
\hline Eq. No. & Parameter & Formula & Description \\
\hline 1 & Density $(\rho)$ & $\rho=\left(\frac{\mathrm{W}_{\mathrm{a}}}{\mathrm{W}_{\mathrm{a}}-\mathrm{W}_{\mathrm{dw}}}\right) \rho_{\mathrm{dw}}$ & $\begin{array}{l}\mathrm{W}_{\mathrm{a}} \text { - Weight of sample in air } \\
\mathrm{W}_{\mathrm{dw}}-\text { Weight of sample in distilled water } \\
\rho_{\mathrm{dw}} \text { - Density of distilled water }\end{array}$ \\
\hline 2 & Molar volume $\left(\mathrm{V}_{\mathrm{m}}\right)$ & $\mathrm{V}_{\mathrm{m}}=\frac{\mathrm{M}_{\mathrm{ave}}}{\rho}$ & $\begin{array}{l}\mathrm{M}_{\text {ave }} \text { - Average molecular weight } \\
\rho \text { - Density }\end{array}$ \\
\hline 3 & $\begin{array}{l}\text { Oxygen packing } \\
\text { density (OPD) }\end{array}$ & $1000 \mathrm{n} \times \frac{\rho}{\mathrm{M}_{\text {ave }}}$ & $\begin{array}{l}n \text { - Number of oxygen atoms per formula } \\
\rho \text { - Density } \\
M_{\text {ave }} \text { - Average molecular weight }\end{array}$ \\
\hline
\end{tabular}

Physical properties

\section{Results and Discussion}

Table 3 shows the result of density and molar volume of $\mathrm{Nd}^{3+}$ doped lead borotellurite glass containing silver and Figure 1 shows the variation of density and molar volume with respect to silver content. As tabulated in the Table 3 , the density of glass was found to increase from $4.969 \mathrm{gcm}^{-3}$ to $5.053 \mathrm{gcm}^{-3}$ with the increasing concentration of $\mathrm{AgNO}_{3}$ from $0.0 \mathrm{~mol} \%$ to $1.0 \mathrm{~mol} \%$ before it start to decrease to $5.028 \mathrm{gcm}^{-3}$ at $1.5 \mathrm{~mol} \%$ of $\mathrm{AgNO}_{3}$. By increasing of some amount of $\mathrm{AgNO}_{3}$, the formation of non-bridging oxygen (NBO) take place and caused the modification of glass network brought extra compactness with higher density but shrinkage in free volume [9]. However, the density of glass seem to decreases slightly at the $1.0 \mathrm{~mol} \%$ of $\mathrm{AgNO}_{3}$. This may be due to the fact that an occupation of $\mathrm{Ag}$ between 1.0 to $1.5 \mathrm{~mol} \%$ in the free space region in the network structure cause the compactness reduction of the glass network [10]. Meanwhile, the result of molar volume of the glass sample decrease from $29.642 \mathrm{~cm}^{3} / \mathrm{mol}$ to $29.169 \mathrm{~cm}^{3} / \mathrm{mol}$ with the increasing concentration of $\mathrm{AgNO}_{3}$ from $0.0 \mathrm{~mol} \%$ to $1.0 \mathrm{~mol} \%$ before it start to increase to $29.324 \mathrm{~cm}^{3} / \mathrm{mol}$ at $1.5 \mathrm{~mol} \%$. This trend of results are expected due to incorporation of $\mathrm{Ag}$ of radii $1.65 \mathrm{pm}$ to replace Te of radii $1.23 \mathrm{pm}$ tend to alter the glass network. This trend results has been observed by Yusof et al. [11].

Table 3. Physical properties of silver addition of lead borotellurite glass.

\begin{tabular}{llcccccc}
\hline \multirow{2}{*}{ Physical Parameters } & \multirow{2}{*}{ Unit } & \multicolumn{7}{c}{ Glass Name } \\
\cline { 3 - 7 } & & S1 & S2 & S3 & S4 & S5 & S6 \\
\hline Density $(\rho)$ & $\left(\mathrm{g} / \mathrm{cm}^{3}\right)$ & 4.969 & 4.980 & 5.053 & 5.028 & 5.031 & 5.071 \\
$\begin{array}{l}\text { Average molecular } \\
\text { weight }\left(\mathrm{M}_{\text {ave }}\right)\end{array}$ & $(\mathrm{g})$ & 147.289 & 147.340 & 147.392 & 147.443 & 147.494 & 147.546 \\
Molar volume $\left(\mathrm{V}_{\mathrm{m}}\right)$ & & & & & & & \\
$\begin{array}{l}\text { Oxygen packing } \\
\text { density }(\mathrm{OPD})\end{array}$ & $\left(\mathrm{cm}^{3} / \mathrm{mol}\right)$ & 29.642 & 29.586 & 29.169 & 29.324 & 29.317 & 29.096 \\
\hline
\end{tabular}

Meanwhile, the oxygen packing density (OPD) is the important parameter to explain the compactness of glass structure [12] and to measure of the tightness of the oxide network [13]. OPD measurements of all glass samples can be calculated using equation 3 from Table 2 and the results are listed in Table 3. As depicted in Figure 2, the OPD seen to vary with respect to silver content. From Figure 2 the OPD are found to increase from 71.015 g.atom/L to $72.508 \mathrm{~g}$.atom $/ \mathrm{L}$ with the increasing of $\mathrm{AgNO}_{3}$ content from $0.0 \mathrm{~mol} \%$ to $1.0 \mathrm{~mol} \%$. However, the values of oxygen packing density drop slightly to 72.295 g.atom/L as the $\mathrm{AgNO}_{3}$ increased to $1.5 \mathrm{~mol} \%$. The results are then start to increase again from 72.483 g.atom $/ \mathrm{L}$ to 73.206 g.atom $/ \mathrm{L}$ as the $\mathrm{AgNO}_{3}$ increase from $1.5 \mathrm{~mol} \%$ to 2.5 mol\%. This results show the similar trends to the density with respect to silver content [14]. 
$\begin{array}{ll}\text { Norihan et al: } & \text { EFFECT OF SILVER ON THE PHYSICAL AND STRUCTURAL PROPERTIES OF LEAD } \\ & \text { NEODYMIUM BOROTELLURITE GLASS SYSTEM }\end{array}$

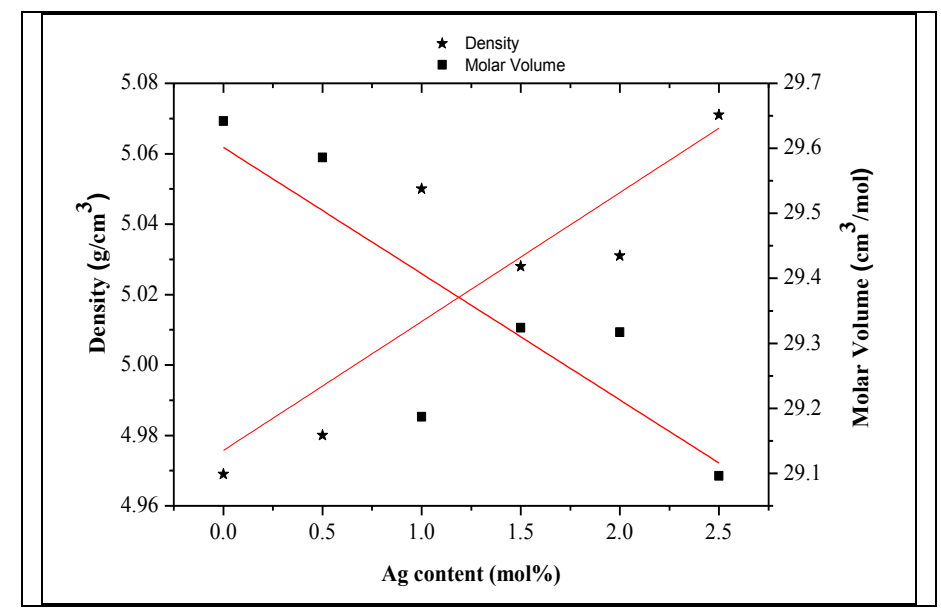

Figure 1. Variation of density and molar volume of silver addition of lead borotellurite glass

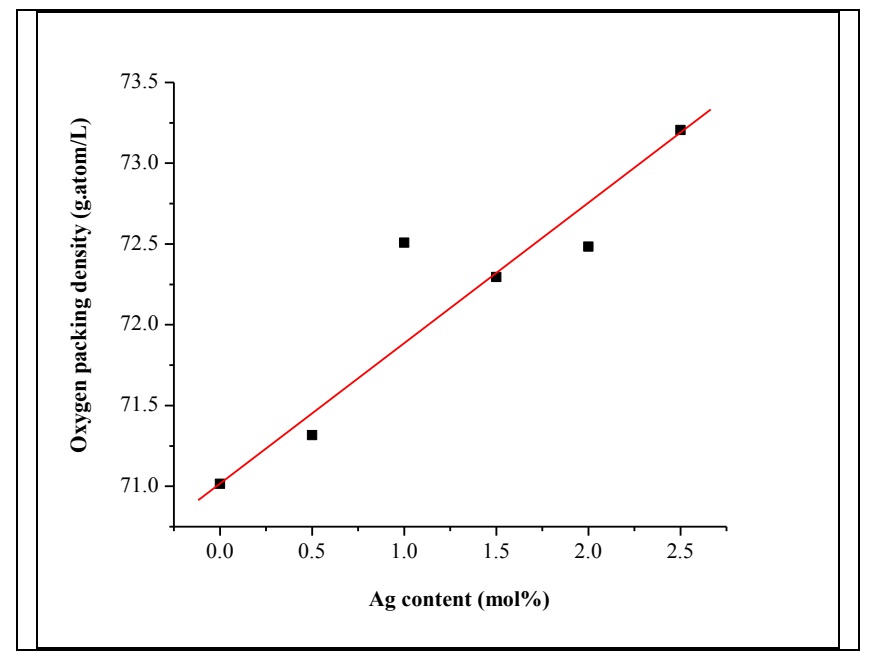

Figure 2. Variation of OPD of silver addition of lead borotellurite glass

\section{Structural properties}

The amorphous nature of the glass system $(69.5-x) \mathrm{TeO}_{2}-20 \mathrm{~B}_{2} \mathrm{O}_{3}-10 \mathrm{PbO}-0.5 \mathrm{Nd}_{2} \mathrm{O}_{3}-x \mathrm{AgNO}_{3}$ with $x$ varying from 0.0 to $2.5 \mathrm{~mol} \%$ of $\mathrm{AgNO}_{3}$ were confirmed through the x-ray diffraction pattern recorded in the range $10^{\circ} \leq \theta \leq 90^{\circ}$ as shown in Figure 3. As in Figure 3, there are no sharp peaks but broad hump diffusion been observed. This confirm the amorphous nature of the glass samples [15]. It can also be observed that the intensity of pattern in all glass samples is slightly different, thus indicating that the glass samples have a different degree of amorphousity. This result shows a good agreement with previous study [16]. 


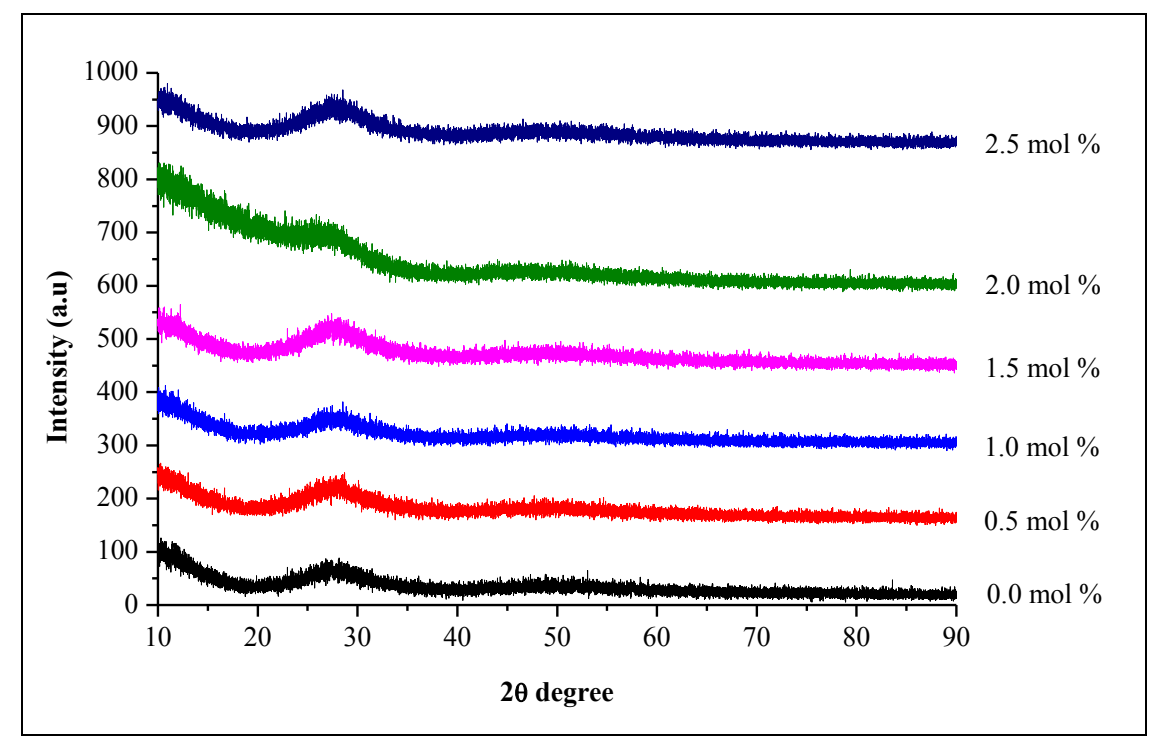

Figure 3. XRD pattern of silver addition of lead borotellurite glass.

In this work, FTIR spectroscopy was carried out in order to identify the existing functional groups peak in the glass networks. Therefore, Figure 4 shows the FTIR spectra of lead borotellurite glass in the range between $400-4000$ $\mathrm{cm}^{-1}$ for different glass compositions. From Figure 4, the FTIR spectra of the borotellurite glasses show six significant IR absorptions bands respectively. Their peak assignments of these glasses are listed in Table 4 based on the literature data on the wavenumber ranges that related to the corresponding vibrations of the structural units in various glassy system.

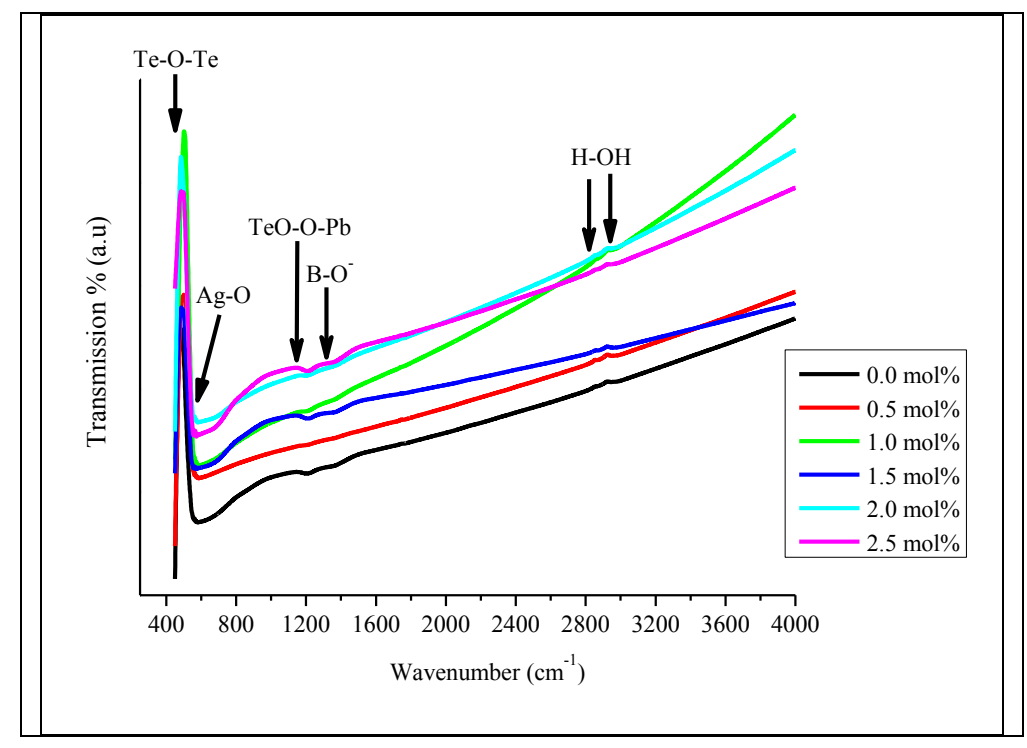

Figure 4. IR spectra of silver addition of lead borotellurite glass 


\section{Norihan et al: EFFECT OF SILVER ON THE PHYSICAL AND STRUCTURAL PROPERTIES OF LEAD NEODYMIUM BOROTELLURITE GLASS SYSTEM}

As can be seen from Table 4, the bands are found in the regions around 460-476 $\mathrm{cm}^{-1}, 552-575 \mathrm{~cm}^{-1}, 1177-1209$ $\mathrm{cm}^{-1}, 1350-1371 \mathrm{~cm}^{-1}, 2872-2880 \mathrm{~cm}^{-1}$ and $2940-2960 \mathrm{~cm}^{-1}$ wavelength respectively. The spectra bands observed between $460 \mathrm{~cm}^{-1}$ and $476 \mathrm{~cm}^{-1}$ are belongs to the Te-O-Te or O-Te-O symmetric stretching vibrations mode at corner sharing sites. This indicates that the vibrations of Te-O-Te or O-Te-O linkage in these glasses are corresponding to the transformation of $\mathrm{TeO}_{4}$ group into $\mathrm{TeO}_{3}$ groups [17]. Meanwhile, the bands around 552-575 $\mathrm{cm}^{-1}$ are assigned to symmetrical bending vibrations of Ag-O bond [18]. The IR absorption at around $1177-1209 \mathrm{~cm}^{-}$ ${ }^{1}$ are attributed to the $\mathrm{Te}-\mathrm{O}-\mathrm{Pb}$ streching vibrations. This result indicates that the addition of $\mathrm{PbO}$ into the glass network could cause a change to the $\mathrm{Te}$ coordination polyhedron from $\mathrm{TeO}_{4}$ trigonal bipyramid (tbp) to $\mathrm{TeO}_{3}$ trigonalpyramid (tp) thus creating more non-bridging oxygen's (NBOs) [19]. The bands occurring in the spectral range 1350-1371 $\mathrm{cm}^{-1}$ are attributed to the $\mathrm{B}-\mathrm{O}$ stretching vibration in $\mathrm{BO}_{3}$ units. These bands are similar reported by Pawar et al. [20]. Finally, the absorption bands located around $2872-2880 \mathrm{~cm}^{-1}$ and $2940-2960 \mathrm{~cm}^{-1}$ are due to the characteristic of the hydrogen bond in the glass samples [21].

Table 4. IR band assignments of silver addition of lead borotellurite glass.

\begin{tabular}{ll}
\hline $\begin{array}{l}\text { Characteristic Bands } \\
\left(\mathbf{c m}^{-1}\right)\end{array}$ & Assignment \\
\hline $460-476$ & $\begin{array}{l}\text { Stretching vibrations modes of Te-O-Te or O-Te-O } \\
\text { Bending vibrations of Ag-O }\end{array}$ \\
$552-575$ & Streching vibrations of Te-O-Pb \\
$1177-1209$ & B-O stretching vibration in $\mathrm{BO}_{3}$ \\
$1350-1371$ & Hydrogen bond \\
$2872-2880$ & Hydrogen bond \\
$2940-2960$ & \\
\hline
\end{tabular}

\section{Conclusion}

A series of glass of the system of $(69.5-x) \mathrm{TeO}_{2}-20 \mathrm{~B}_{2} \mathrm{O}_{3}-10 \mathrm{PbO}-0.5 \mathrm{Nd}_{2} \mathrm{O}_{3}-x \mathrm{AgNO}_{3}$ where $x=0.0,0.5,1.0,1.5,2.0$ and $2.5 \mathrm{~mol} \%$ have been well fabricated as they are in a good quality as visualized. The density of the glasses increased from $4.969 \mathrm{gcm}^{-3}$ to $5.053 \mathrm{gcm}^{-3}$ while their molar volume values decreases from $29.642 \mathrm{~cm}^{3} / \mathrm{mol}$ to $29.169 \mathrm{~cm}^{3} / \mathrm{mol}$ with respect to $\mathrm{AgNO}_{3}$ content. The oxygen packing density (OPD) show the same trend to the density as they vary from 71.015 g.atom/L to 73.206 g.atom/L with respect to $\mathrm{AgNO}_{3}$ content. The $\mathrm{XRD}$ results confirmed fact the glasses obtained are amorphous in nature. The FTIR spectra indicated the presence of Te-O-Te or $\mathrm{O}-\mathrm{Te}-\mathrm{O}, \mathrm{Ag}-\mathrm{O}, \mathrm{Te}-\mathrm{O}-\mathrm{Pb}$ and $\mathrm{B}-\mathrm{O}$ functional group of the glass network.

\section{Acknowledgements}

The author wishes to thanks Ministry of Education (MOE), Malaysia for the Research Acculturation Grant Scheme (RAGS) research grant and UiTM Pahang for the encouragement and support.

\section{References}

1. Selvi, S., Venkataiah, G., Arunkumar, S., Muralidharan, G. and Marimuthu, K. (2014). Structural and luminescence studies on $\mathrm{Dy}^{3+}$ doped lead boro-telluro-phosphate glasses. Physica B, 454: 72-81.

2. Karthikeyan, P., Vijayakumar, R. and Marimuthu, K. (2017). Luminescence studies on $\mathrm{Dy}^{3+}$ doped calcium boro-tellurite glasses for White light application.. Physica B, 521: 347-354.

3. Selvaraju, K. and Marimuthu, K. (2012). Structural and spectroscopic studies on concentration dependent $\mathrm{Er}^{3+}$ doped boro-tellurite glasses. Journal of Luminescence, 132: 1171-1178.

4. Sasikala, T., Rama Moorthy, L. and Mohan Babu, A. (2013). Optical and luminescent properties of $\mathrm{Sm}^{3+}$ doped tellurite glasses. Spectrochimica Acta Part A: Molecular and Biomolecular Spectroscopy, 104: 445-450.

5. Maheshvaran, K., Linganna, K. and Marimuthu, K.. (2011). Composition dependent structural and optical properties of $\mathrm{Sm}^{3+}$ doped boro-tellurite glasses. Journal of Luminescence, 131: 2746-2753.

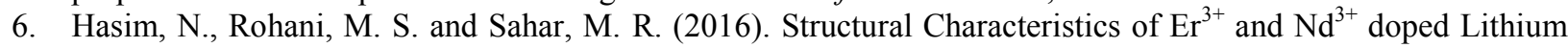
Niobate Tellurite Glass. Materials Science Forum, 846: 126-130. 
7. Linganna, K., Narro-García, R., Desirena, H., De la Rosa, E., Basavapoornima, Ch., Venkatramu, V. and Jayasankar, C. K. (2016). Effect of $\mathrm{P}_{2} \mathrm{O}_{5}$ addition on structural and luminescence properties of $\mathrm{Nd}^{3+}$-doped tellurite glasses. Journal of Alloys and Compounds, 684: 322-327.

8. Reza Dousti, M. and Raheleh Hosseinian, S. (2014). Enhanced upconversion emission of $\mathrm{Dy}^{3+}$-doped tellurite glass by heat-treated silver nanoparticles. Journal of Luminescence, 154: 218-223.

9. Ashur, Z., Mahraz, S., Sahar, M. R. and Ghoshal, S. K. (2015). Enhanced luminescence from silver nanoparticles integrated $\mathrm{Er}^{3+}$-doped boro-tellurite glasses: Impact of annealing temperature. Journal of Alloys and Compounds, 649: 1102-1109.

10. Huang, B., Zhou, Y., Cheng, P., Zhou, Z., Li, J. and Yang, G. (2016). The $1.85 \mu \mathrm{m}$ spectroscopic properties of $\mathrm{Er}^{3+} / \mathrm{Tm}^{3+}$ co-doped tellurite glasses containing silver nanoparticles. Journal of Alloys and Compounds, 686: 785-792.

11. Yusoff, N. M. and Sahar, M. R. (2015). Effect of silver nanoparticles incorporated with samarium-doped magnesium tellurite glasses. Physica B, 456: 191-196.

12. Terny, S., De la Rubia, M.A., Alonso, R. E., J. de Frutos and Frechero, M. A. (2015). Structure and electrical behavior relationship of a magnesium-tellurite glass using Raman and impedance spectroscopy. Journal of Non-Crystalline Solids, 411: 13-18.

13. Farouk, M., Samir, A., Metawe, F. and Elokr, M. (2013). Optical absorption and structural studies of bismuth borate glasses containing $\mathrm{Er}^{3+}$ ions. Journal of Non-Crystalline Solids, 371-372: 14-21.

14. Farag, M. A., Abd-Allah, K., Turky, G. and Alokr, M. M. (2015). Optical and Upconversion properties of Nd ${ }^{3+}$ doped lead borate barium glass system. Nature and Science, 13(5): 123-129.

15. Ratnakaram, Y. C., Babu, S., Krishna Bharat, L. and Nayak, C. (2016). Fluorescence characteristics of $\mathrm{Nd}^{3+}$ doped multicomponent fluoro-phosphate glasses for potential solid-state laser applications. Journal of Luminescence, 175: 57-66.

16. Azevedo, J., Coelho, J., Hungerford, G. and Sooraj Hussain, N. (2010). Lasing transition $\left({ }^{4} \mathrm{~F}_{3 / 2}{ }^{4} \mathrm{I}_{11 / 2}\right)$ at $1.06 \mu \mathrm{m}$ in neodymium oxide doped lithium boro tellurite glass. Physica B, 405: 4696-4701.

17. Surendra, B. S., Rajeswari, R., Kiwan, J. Cho, E. J., Kyoung, H. J., Hyo, J. S. and Jayasankar, C. K. (2010). Spectroscopic investigations of $1.06 \mu \mathrm{m}$ emission in $\mathrm{Nd}^{3+}$-doped alkali niobium zinc tellurite glasses. Journal of Luminescence, 130: 1021-1025.

18. Bolundut, L., Culea, E., Borodi, G., Stefan, R., Munteanu, C. and Pascuta, P. (2015). Influence of $\mathrm{Sm}^{3+}: \mathrm{Ag}$ codoping on structural and spectroscopic properties of lead tellurite glass ceramics. Ceramics International, 41: 2931-2939.

19. Nurbaisyatula, E. S., Azman, K., Azhan, H., Razali, W. A. W. and Noranizah, A. (2014). The structural properties of trivalent rare earth ions $\left(\mathrm{Er}^{3+}\right)$ doped borotellurite glass. Jurnal Teknologi, 69(2): 97-100.

20. Pawar, P. P., Munishwar, S. R. and Gedam, R. S. (2016). Physical and optical properties of $\mathrm{Dy}^{3+} / \mathrm{Pr}^{3+}$ Co-doped lithium borate glasses for W-LED. Journal of Alloys and Compounds, 660: 347-355.

21. Vijayalakshmi, L., Naveen, K. and Vijayalakshmi, R. P. (2016). Energy transfer based photoluminescence spectra of co-doped $\left(\mathrm{Dy}^{3+}+\mathrm{Sm}^{3+}\right)$ : $\mathrm{Li}_{2} \mathrm{O}-\mathrm{LiF}-\mathrm{B}_{2} \mathrm{O}_{3}-\mathrm{ZnO}$ glasses for orange emission. Optical Materials, 57: 125-133. 